\title{
Secondary Bacterial Infections Complicating Psoriasis
}

\author{
Shehab A. Lafi ${ }^{1}$, Abdullah S.-Hasan ${ }^{2}$ and Muntaha M. Al-Alowssi ${ }^{1}$ \\ 1- Microbiology Department, College of Medicine, AL-Anbar University. \\ 2- Dermatology Department, College of Medicine, Al-Anbar University.
}

\begin{abstract}
Background: Psoriasis is a chronic lifelong skin disease most commonly causing erythematous popular and scaly plaques depending on lesion type. Secondary bacterial invaders complicate such lesions. Objectives of this study were to detect the types of aerobic and anaerobic bacterial invaders commonly complicate psoriatic lesions.

Patients and Methods: Swabs were taken from different lesions of different sites of patients with psoriasis. Specimens were examined bacteriologically as soon as possible (within one hour) by direct gram stained smears were examined microscopically and indirectly by cultivation aerobically and anaerobic using suitable culture media and cultivation environments. Bacterial isolates were diagnosed and confirmed using suitable diagnostic techniques.

Results: Psoriasis was found higher in individuals of age group (18-40) years old and majority of them $(38 ; 48.7 \%)$ were showing distributed psoriatic lesions whole over the body. Staphylococcus aureus took the first rank of isolation 23 (29.5\%). Proteus spp. and Staphylococcus epidermidis became next 11 and 9 for each respectively. Other bacterial isolates were showed lower rate of isolation like Pseudomonas aeruginosa, Bacillus spp. Enteric bacteria were primarily isolated from children. Also, E. coli and Enterococcus fecalis. Anaerobic bacteria represented by Propionobacter spp., Fusarium spp. and Clostridium perfringens were isolated within few numbers $(3,2,1)$ for each respectively.

Conclusion: Secondary bacterial infections of different types complicate psoriatic lesions on different sites of the body, so we recommended the follow up of perfect sanitation and disinfection with suitable antimicrobial regimen to reduce infection hazards.
\end{abstract}

Keywords: Psoriasis, Bacteria, Infected psoriasis

\section{INTRODUCTION}

Psoriasis is a chronic lifelong skin disease most commonly causing erythematous popular and scaly plaques depending on lesion type, Gudionsson, E. J. et al. (2003); and Guo-li, et al. 2009. Psoriasis is a chronic immunologically based inflammatory disease of the skin and joint, which has been estimated to affect $1-3 \%$ of population. The exact cause is unknown, however researches believe heredity, environment and immune system also play a role in psoriasis Gudionsson, E. J. et al. (2003). and Hwerta, C. et al. (2007).

Several overlapping clinical types of disease have been identified but the chronic plaque form (Psoriasis vulgaris) is the most common Gudionsson, E. J. et al. (2003). and Mallbris, L. et al. (2005).

Psoriasis is a common T-lymphocyte mediated inflammatory skin disease believed to have an autoimmune basis.

The link between psoriasis and infection is probably explained by the superantigen theory, that superantigens are the products of bacteria, viruses, or fungi, which can bypass normal immunological pathway and cause powerful stimulation to the immune system. Studies imply that a protein called the M protein carried by $S$. pyogenes acts as superantigen in provoking psoriasis, Beaker, B.S. et al. (2006). 
Secondary infected dermatosis develops when a bacterium invades compromised skin such as psoriasis, Brook, I. et al.2002. This study aimed to detect the types of aerobic and anaerobic bacterial invaders commonly complicate psoriatic lesions.

\section{Patients and Methods}

Seventy eight (78) patients with different types of psoriasis from both sexes and different residence sites of Ramadi District, West of Iraq, were included in this study. Patients were attending Ramadi General Hospital, Clinic of Skin and Venereal Diseases and Private Clinics of Dermatology in Ramadi City during the period extended from January to July 2009.

Patients were examined by Senior Dermatologist for the diagnosis and follow up of their treatment. Information about each patient was reported using questionnaire for each one. Bacteriological swabs were taken aseptically from different lesions and sites of psoriasis. Specimens were processed as soon as possible for bacteriological investigation through direct Gram stained smears and indirect examination by cultivation on blood agar, chocolate agar and MacConkey agar and incubated at $37{ }^{\circ} \mathrm{C}$ for $24-48 \mathrm{hrs}$ aerobically and anaerobically using Gas pack anaerobic Gas sheets (Oxoid).
Special culture media and techniques were employed for the diagnosis of some bacterial isolates on need. Bacterial isolates diagnosis was confirmed using morphological and culture characters following (Washington $\mathrm{et} \mathrm{al}^{7}$.).

Data were reported and analyzed using SPSS Program.

\section{RESULTS}

\section{Age, sex and residence}

Psoriasis was found higher in individuals of age group (18-40) years old $(49,62.8 \%)$ and both sexes (28 males and 21 females) (Table1). Significant difference $(\mathrm{P}<0.05)$ was found between males and females in group (18-40) and (41-50) years old patients. Urban males and rural females were showing higher rate of psoriasis in age group (1-17) year $(45.5 \%), 36.5 \%)$ for each respectively (Table1). All patients within age group $>50$ years from both sexes were rural. Regarding site of psoriasis, majority of patients (38, $48.7 \%$ ) were showing distributed psoriasis lesion whole over the body followed by hands and legs $(26,33.4 \%)$ (Table 2).

Table 1: Psoriatic patients regarding age, sex, and residence.

\begin{tabular}{|c|c|c|c|c|c|}
\hline \multirow{2}{*}{$\begin{array}{l}\text { Age } \\
\text { group } \\
\text { (Year) }\end{array}$} & \multicolumn{2}{|c|}{ Urban } & \multicolumn{2}{|c|}{ Rural } & \multirow{2}{*}{ Total } \\
\hline & Male & Female & Male & Fermale & \\
\hline \multirow{2}{*}{$1-17$} & 5 & 1 & 1 & 4 & 11 \\
\hline & $45.5 \%$ & $9.0 \%$ & $9 \%$ & $36.5 \%$ & $14 . \%$ \\
\hline \multirow{2}{*}{$18-40$} & 14 & 10 & 14 & 11 & 49 \\
\hline & $28.6 \%$ & $20 \%$ & $28.6 \%$ & $22.4 \%$ & $62.8 \%$ \\
\hline \multirow{2}{*}{$41-50$} & 2 & 1 & 6 & 2 & 11 \\
\hline & $18.2 \%$ & $9.1 \%$ & $54.5 \%$ & $18.2 \%$ & $14.1 \%$ \\
\hline \multirow{2}{*}{$>50$} & 0 & 0 & 4 & 3 & 7 \\
\hline & 0 & 0 & $57.2 \%$ & $42.8 \%$ & $9 \%$ \\
\hline \multirow{2}{*}{ Total } & 21 & 12 & 25 & 20 & 78 \\
\hline & 27 & 15.4 & $32 \%$ & $25.6 \%$ & $100 \%$ \\
\hline
\end{tabular}

Table 2: Numbers of patients regarding psoriasis anatomical sites.

\begin{tabular}{|c|c|c|c|c|c|}
\hline \multirow{2}{*}{$\begin{array}{c}\text { Age group } \\
\text { (Year) }\end{array}$} & \multicolumn{4}{|c|}{ Site of the lesion } & \multirow{2}{*}{ Total } \\
\cline { 2 - 6 } & Head and Neck & Trunk & Hands and Legs & $\begin{array}{c}\text { Whole of the } \\
\text { Body }\end{array}$ & 13 \\
\hline $1-17$ & 0 & 0 & 2 & 11 & 18 \\
\hline $18-40$ & 6 & 5 & 18 & 4 & 10 \\
\hline $41-50$ & 1 & 0 & 5 & 5 & 8 \\
\hline$>50$ & 2 & 0 & 1 & 38 & 78 \\
\hline Total & 9 & 5 & 26 & $48.7 \%$ & $100 \%$ \\
\hline
\end{tabular}




\section{Bacterial Isolation}

All specimens from patients were showing positive bacterial growth. The total number of bacterial isolates was (95), Seventy eight (78) of them were isolated as single bacterial isolates, while the rest (17) were showing mixed bacterial isolation (Tables $3 \& 4$ ).

Staphylococcus aureus took the first rank of isolation $(23,29.5 \%)$ and most of isolates were isolated from lesions on hands and legs (Table-3). Proteus species. and Staphylococcus epidermidis became next (11 and 9) for each respectively. Pseudomonas aeruginosa, Bacillus species. (non anthrax) and E.coli were showing equal rate of isolation, (6) for each.
Other bacterial isolates were showing lower rate of isolation (Table 3).

Anaerobic bacterial types represented by Propionobacter spp. Fusarium and Clostridium perfringens were showing low number of isolation, $(3,2,1)$ for each respectively (Table 3$)$.

Regarding mixed bacterial isolation, Staphylococcus aureus showed the highest rate of mixed isolation $(7,53.8 \%)$ followed by E.coli and Staphylococcus epidermidis, (4) isolates for each (Table 4).

Enteric bacterial types were mostly isolated from hands, legs and whole of the body from children within age group (1-17) years old patients.

\begin{tabular}{|c|c|c|c|c|c|}
\hline Bacterial Isolates & $\begin{array}{c}\text { Head } \\
\text { and } \\
\text { Neck }\end{array}$ & Trunk & $\begin{array}{c}\text { Hands } \\
\text { and } \\
\text { Legs }\end{array}$ & $\begin{array}{l}\text { Whole of } \\
\text { the Body }\end{array}$ & $\begin{array}{l}\text { Total } \\
\text { No. } \\
(\%)\end{array}$ \\
\hline Staphyiococcus auraus & 6 & 2 & 9 & 6 & 23 \\
\hline $\begin{array}{l}\text { Staphylococcus } \\
\text { epidermidis }\end{array}$ & 2 & 1 & 4 & 2 & (11.5) \\
\hline Bacilizus spp. & 1 & 0 & 3 & 1 & 5 \\
\hline Proteus spp. & 2 & 1 & 5 & 2 & $\begin{array}{l}10 \\
(12.7)\end{array}$ \\
\hline E. coli & 1 & 0 & 4 & 1 & 6 \\
\hline Psendomonas aeruginosa & 1 & 0 & 3 & 2 & 6.72 \\
\hline Streptococcus pyogenes & 1 & 2 & 3 & 0 & 67.7 \\
\hline $\begin{array}{l}\text { Corynebacterium } \\
\text { (non diphtheria) }\end{array}$ & 1 & 0 & 1 & 2 & $45.1\rangle$ \\
\hline Enterococcus fecalis & o & o & 2 & 1 & 3 \\
\hline Propionobacter spp. & 1 & 0 & 2 & 0 & 3 \\
\hline Fisarium spp. & 1 & 0 & 1 & 0 & 2 \\
\hline Clostricium perfingens & 0 & 1 & 0 & 0 & $1(1.3)$ \\
\hline Total & 17 & 7 & 37 & 17 & $\begin{array}{l}78 \\
(100)\end{array}$ \\
\hline
\end{tabular}

Table 4: Mixed bacterial isolates regarding anatomical sites of psoriasis

\begin{tabular}{|l|c|c|c|c|c|}
\hline \multicolumn{1}{|c|}{ Bacterial Isolates } & $\begin{array}{c}\text { Head } \\
\text { and Neck }\end{array}$ & Trunk & $\begin{array}{c}\text { Hands } \\
\text { and Legs }\end{array}$ & $\begin{array}{c}\text { Whole of } \\
\text { the Body }\end{array}$ & Total \\
\hline $\begin{array}{l}\text { Staphylococcus aureus }+ \\
\text { Bacillus spp. }\end{array}$ & 1 & 0 & 1 & 0 & 2 \\
\hline $\begin{array}{l}\text { E. coli + } \\
\text { Staphylococcus aureus }\end{array}$ & 0 & 1 & 2 & 1 & 4 \\
\hline $\begin{array}{l}\text { Pseudomonas aeruginosa } \\
+\end{array}$ & 1 & 0 & 1 & 0 & 2 \\
\hline $\begin{array}{l}\text { Proteus spp. } \\
\text { Staphylococcus aureus }\end{array}$ & 1 & 0 & 1 & 2 & 4 \\
\hline $\begin{array}{l}\text { Staphylococcus aureus + } \\
\text { Fusarium spp. }\end{array}$ & 0 & 0 & 1 & 0 & 1 \\
\hline Total & 3 & 1 & 6 & 3 & 13 \\
\hline
\end{tabular}




\section{DISCUSSION}

Higher psoriasis rate $(62.8 \%)$ in patients within age group (18-40) years old was in accordance with the findings of, (Hwerta, C. et al. 2007 and Zieve, d. et al.2008).

These findings disagree with the findings of ${ }^{(1)}$ who found that psoriasis particularly psoriasis vulgaris was higher and common in individuals within (4050) years old.

Discrepancy of resulta in contrast to other investigators might be due to difference of patient samples and type of psoriasis, (guttate type) mostly mediated early with $S$. pyogenes recurrent tonsillitis which is most common infection in children who showed more guttate psoriasis type, Guo-li et al. (2009) and Owen, C., et al. (2001). Guttate psoriasis type is mostly mediated by $S$. pyogenes superantigen, Gudionsson, E. J. et al. (2003).

Residence (urban and rural) was not affecting psoriasis rate particularly patients of higher rate within age group (18-40) years old, this might be ought to the nature of psoriasis, which is primarily autoimmune triggered disease, Gudionsson, E. J. et al. 2003; Beaker, B.S. et al. 2006 and National Psoriasis Foundation NPF National Psoriasis Foundation NPF (2010). This immune reaction leads to infiltration of inflammatory cells and increased proliferation turnover of keratinocytes, Mallbris, L. et al. All patients above 50 years old were rural, this might be due to the small sample size in this study which affects the distribution of patients regarding residence and socioeconomic status. Socioeconomic status of patients affects indirectly on the degree of effectiveness of disease via affecting immune status, sanitation and treatment. Age also affects psoriasis incidence through immune system modulation, aged individuals show decrease in CD8 T-cells and more shift to autoimmunity through break of autotoleance, National
Psoriasis Foundation NPF (2010) and Rosen, S.F. 2007.

In all age groups (18-40), (41-50) and $(>50)$ years old, males were showing more psoriasis rate, this was in accordance with Hwerta et al. 2007.

\section{Bacterial Isolation}

Regarding bacterial isolation from psoriatic patient lesions of different sites, Staphylococcus aureus was predominant isolated bacteria, this was in agreement with previous referees, Gudionsson, E. J. et al. 2003; Brook, I. et al. 2002 and Abdullah, M. et al. 2007. Staphylococcus aureus was the commonest organism causing secondary infections of skin lesions, this might be attributed to the antiphagocytic effect of protein A of this organism, as well as the inhibitory effect of serum exuding from denuded skin on linolenic acid an essential fatty acid normally present on the intact skin inhibits Staphylococcus aureus colonization, Gudionsson, E. J. et al. 2003 and Brook, G.F. et al. 2007.

Similarity in most of bacterial infections for psoriatic lesions and other dermatological affections like atopic dermatitis, eczema and scabies, Brook, I. et al. 2002; Rosen, S.F. 2007 and Lafi, S.A.; et al. 2008. Isolation of opportunistic pathogens from psoriatic lesions like Bacillus species. (non anthrax type) (Anthracoid spp.) and Staphylococcus epidermidis was ought to the reduced local defense factors in the lesion due to local and systemic immunosuppressant drugs like cytotoxic drugs and cortisones used for the treatment of psoriasis, Zieve, d. et al. 2008 and National Psoriasis Foundation NPF, 2010.

In addition to that, antiphagocytic activity of certain factors released by actual pathogens previously invade psoriatic lesion like Staphylococcus aureus protein A, such Staphylococcus aureus predispose invasion by opportunistic pathogens, Gudionsson, E. J. et al. 2003 and Lafi, S.A. 2008. 
Isolation of anaerobic bacteria was different from that reported by previous researchers, Gudionsson, E. J. et al. 2003; Brook, I. 2002 and Abdullah, M. et al. 2007, lower rate of isolation of Fusarium, Propionobacter and Clostridium spp. was reported in this study, in addition to that Bacteroides and Prevotella were not isolated from specimens of this study.

This difference might be attributed to many factors affecting residence and transient skin flora like patient rate and residence, habits, socioeconomics status, as well as other patients personal status and environmental factors, (Proceeding of National Academy of Science 2007).

Enteric bacterial species like E. coli, Enterococcus fecalis, Proteus spp. were isolated primarily from children particularly lesions from hands, legs and whole of the body, this was in accordance with the findings of (Brook, I. et al. 2002; Abdulla, M. et al. 2007). This was probably ought to the low personal care and sanitation criteria of patients particularly children.

The recovery of multiple organisms from psoriatic lesions of patients illustrated the polymicrobial nature of secondarily infected psoriasis and the potential for bacterial synergy between different microbial isolates, Brook, I. et al. 2002; Washington, W. J .r. et al. 2006 and Harry, J. et al. 2008.

We concluded that psoriatic lesions of different types and sites of the body undergo contamination and bacterial infections and probably with other organisms like fungi, viruses, etc. So we recommend the follow up of perfect sanitation and disinfection of the lesion with suitable antimicrobial regimen to prevent complications and invader disposal.

\section{REFERENCES}

Abdullah, M.; Zaki, M.; EL-Sayed, A. and Erfan, D. (2007). Evaluation of secondary bacterial infection of skin diseases in Egyptian in- and out- patients and their sensitivity to antimicrobials. Egyptian Dermatology Online J. 3 (2): 1-16.

Beaker, B.S.; Powles, A.; Fry, Z. (2006). Peptidoglycan: a major etiological factor for psoriasis? Trends Immunol. 27: 545-551.

Brook, G.F.; Carrol, C.K.; Butel, S.J. and Morse, A. S. (2007). Normal microbial flora of the human body. In: Jawetz, Melnick and Adelberg's Medical Microbiology $24^{\text {th }}$ Ed. P: 197-202. McGraw-Hill Public. New York USA.

Brook, I. (2002). Secondary bacterial infections complication skin lesions. J. of Med. Microbiology. 51: 808812.

Gudionsson, E. J.; Thorarisson, A. M.; Sigurgeresson, B. et al. Clinical and laboratory investigations Streptococcal throat infections and exacerbation of chronic plaque psoriasis: a prospective study. British J. of Dermatology.

Guo-li, Lixiu-Yan, Wang, Ming-Yi et al. (2009). Cell wall-deficient bacteria a major etiological factor for psoriasis. Chinese Med. J. 122 (24): 30113016.

Harry, J.; Bayer, E. A.; Rincon, M. T. et al. (2008). polysaccharide utilization by gut bacteria: potential for new insights from genomic analysis. Nature Reviews Microbiology, 6: 126-133.

Hwerta, C.; Rivero, E.; Luis, A. et al. (2007). Incidence and risk factors for psoriasis in the general population. Arch. of Dermatology, 143 (12): 1559-1565.

Lafi, S. A.; Zaynab, K.; Yousif, (2008). Bacterial aspects of Eczema. ALAnbar J. for Basic Science. 2: 2 617.

Mallbris, L. et al. (2005). Psoriasis phenotype at disease out set: Clinical characterization of 400 adult cases. J. Invest. Dermatol., 124: 499-504.

National Psoriasis Foundation NPF (2010). What is known about psoriasis immune system involvement? Internet www.psoriasis.org/net.

Owen, C.; Chalmers, G.J.R.; Osullivon, F. et al. (2001). A systemic review of 
antistreptococcal interventions for guttate and chronic plaque psoriasis. Br. J. of Dermatology. 145: 886-890. Proceeding of National Academy of Science, Feb. 5-2007. www.sciencedaily.com.

Rosen, S. F. Immunodeficiency in male D., Brostoff J., Roth B. D. and Roitts Immunology $17^{\text {th }}$ Ed. 2007, Mosby Public. P.995 New York USA. 149:530-534.
Washington, W. J .r.; Stephen, A.; William, J. et al. (2006). Konemans color atlas and textbook of diagnostic Microbiology. $6^{\text {th }}$ Ed. Lippincott, Williams and Wilkins Publisher London UK.

Zieve, d.; Grey, M. H. A.; Juha, MTPW. and Eitd, K. D. (2008). Psoriasis online encyclopedia

www.mlm.nihgov, medlineplus/ency.

\section{ARABIC SUMMARY}

$$
\begin{aligned}
& \text { الأخماج الجرثومية الثانوية المعقدة لداء الصدفية }
\end{aligned}
$$

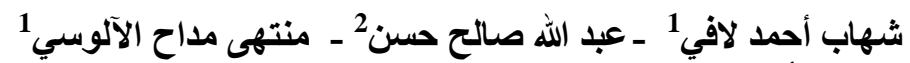

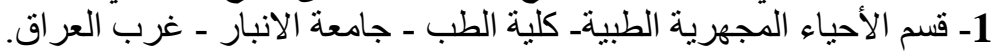

$$
\begin{aligned}
& \text { 2- قسم الجلدية_ كلية الطب - جامعة الانبار - غرب العانبة العراق. }
\end{aligned}
$$

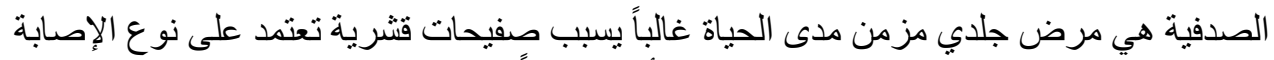

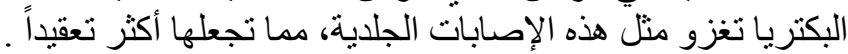

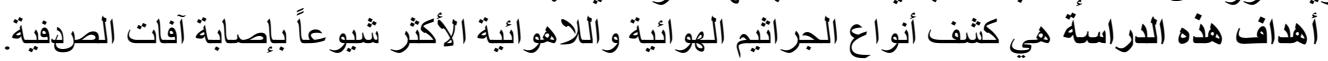

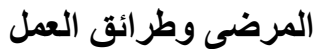

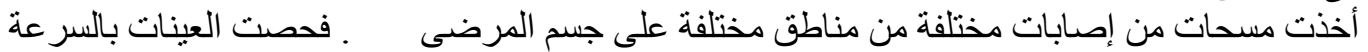

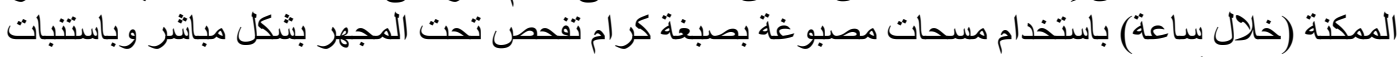

$$
\begin{aligned}
& \text { المسحات على أوساط زر عيه مناسبة. شخصت العز لات الجرثو مية باستخدام تقانات تشخيصية مناسبة. }
\end{aligned}
$$

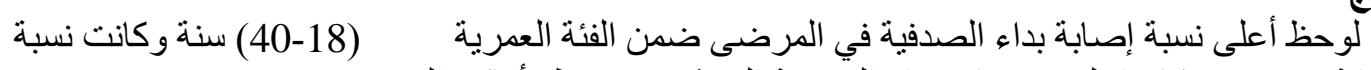

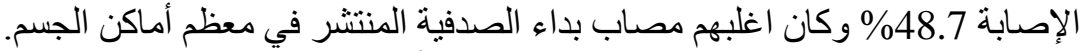

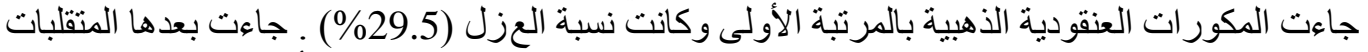

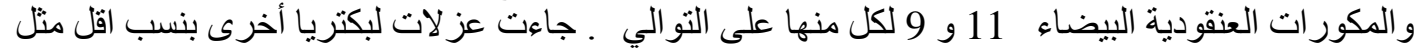

$$
\begin{aligned}
& \text { الزو ائف الزنجارية و العصيات. } \\
& \text { عزلت الجر اثيم المعوية مثل الاشريكيا القولونبة و المكورات المعوية بنسبة أعلى في الأطفال. }
\end{aligned}
$$

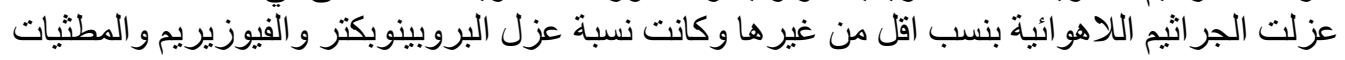

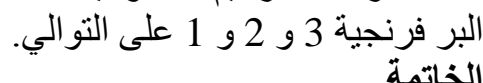

$$
\begin{aligned}
& \text { الاخماج البكتيرية الثانوية المختلفة تعقد أفات الصدفية في مختلف الأماكن و عليه نوصي بإتباع وسائل } \\
& \text { التطهير وباستخدام مضادات الجر اثيم لتتبيط مخاطر الخمّة }
\end{aligned}
$$

